\title{
Além do Rio - uma Medea na dramaturgia do teatro negro no Brasil
}

\section{Além do Rio-a Medea in the dramaturgy of black in Brazil}

Adelia Aparecida da Silva Carvalho ${ }^{1}$ 


\section{Resumo}

Este artigo propõe uma reflexão sobre a dramaturgia do teatro negro a partir do texto teatral Além do rio (Medea), de Agostinho Olavo, escrito em 1957, uma releitura da tragédia grega Medeia, de Eurípides. A partir dele, buscamos refletir sobre a proposta estética presente na elaboração da dramaturgia de um Teatro Negro através de alguns elementos, tais como a inversão de valores no que diz respeito à temática, à composição de personagens e à linguagem construindo ainda uma relação com o ritual, a musicalidade e a estrutura cíclica tão presente na cultura negra.

Palavras-chave: Medeia; teatro negro; dramaturgia.

\section{Abstract}

This article proposes a reflection on the dramaturgy of black theater taking as its starting point the theatrical text Além do rio (Medea), by Agostinho Olavo, written in 1957, a retelling of the Greek tragedy Medea by Euripides. We reflect on the aesthetic proposal present in the formation of the dramaturgy of a Black Theatre by analyzing the inversion of values with regard to the theme, character composition and language. Furthermore, we develop these aspects in relation to ritual, musicality and the cyclic structure present in black culture.

Keywords: Medea; black theatre; dramaturgy.
ISSN: 1414.5731

E-ISSN: 2358.6958 


\section{Além do rio e o teatro negro brasileiro}

O autor Agostinho Olavo escreveu, em 1957, a peça Além do rio, apoiando "a concepção do drama em três bases: a tragédia grega, de que adapta o enredo, as cantigas folclóricas e os cantos dos ritos afro-brasileiros" (Martins, 1991, p. 131). Tal mistura já aponta para uma característica dessa escrita negra que, ao contrário da ideia de pureza tão difundida pelo mito ariano² e da ameaça de apagamento, dissimulada no pensamento da mestiçagem ${ }^{3}$, busca a exaltação de cada uma das identidades presentes, colocando a mistura como elemento iluminador das diferenças para a formação do texto dramático.

A peça, inspirada em Medeia, de Eurípides,

[c]onta a história de uma rainha africana escravizada e trazida para o Brasil do século XVII. Feita amante do senhor branco, ela trai sua gente, é desprezada pelos ex-súditos escravizados. Chega o dia do amante querer um lar, um casamento normal com uma esposa branca, de posição social. Rompe sua ligação com Medéa, mas quer levar os filhos. A rainha mata seus próprios filhos, no rio, e retorna a seu povo, convocando: “- Vozes, ó vozes da raça, ó minhas vozes, onde estão? Por que se calam agora? A negra largou o branco. Medéa cospe este nome e Jinga volta à sua raça, para de novo reinar!” (Nascimento, 2004, p. 218).

Se um autor, principalmente quando ligado a um movimento negro ao qual se estendem tantos preconceitos, "só fala da sua própria experiência de vida, seu texto passa despercebido dos seus contemporâneos. É preciso que aprenda primeiro a falar a língua da metrópole para melhor combatê-la em seguida" (Santiago, 1978, p. 22). A Medeia grega fez isso, conta Eurípides. Olavo irá se apropriar dessa personagem e desse recurso tanto como comprovação da universalidade desses textos, quanto para dar maior visibilidade ao trabalho, trazendo os olhares para uma nova contextualização e colocando em foco a personagem negra e as suas questões, através desse diálogo.

Uma primeira possibilidade de caracterização do Teatro Negro stricto sensu pode ser abstraída da própria história desse teatro, nas vozes que o têm presentificado, nos espelhos em que ele procura se definir. Essa tentativa de autodefinição às vezes antecede a elaboração de uma dramaturgia específica e traduz-se na atitude de apropriação e reelaboração de peças já consagradas pela tradição européia. Reencenados em casas teatrais à margem dos circuitos comercias, muitos textos eram recriados em montagem que primavam por uma tradução que os inseria na linguagem cênica da tradição teatral negra (Martins, 1991, p. 66).

\footnotetext{
2 "'O mito ariano é sem dúvida uma construção do século XIX proliferado nas sociedades europeias principalmente ao longo do século XX no âmbito de debate nacionalista maior, porém, suas referências encontram raízes mais antigas e remontam ao próprio antigo testamento. Quando nos referimos ao conceito de arianismo a partir da perspectiva do mito é porque entendemos que a sua construção é muito mais ideológica que propriamente científica ou epistemológica. Segundo seus defensores, a superioridade ariana foi provada tanto cientificamente, por meio das teorias eugênicas do século XIX, como his-
}

toricamente, por meio do mito dos três reinados ou reich" (Paula, 2011, p. 7). 3 "A mestiçagem, como articulada no pensamento brasileiro entre o fim do século XIX e meados do século XX, seja na sua forma biológica (miscigenação), seja na sua forma cultural (sincretismo cultural), desembocaria numa sociedade uniracial e unicultural. Uma tal sociedade seria construída segundo o modelo hegemônico racial e cultural branco ao qual deveriam ser assimiladas todas as outras raças e suas respectivas produções culturais" (Munanga, 2008, p. 85) 
Tal apropriação, muito mais do que o sentido que aparenta à primeira vista, de subserviência à cultura ocidental branca, busca realizar o diálogo entre ela e a tradição africana, propondo uma reflexão sobre esse ir e vir de influências e ainda propondo o apuro da percepção sobre a resistência da cultura negra, diante das tentativas de apagamento que a cercam.

Agostinho Olavo não era negro, mas tinha ligação com as aspirações do TEN - Teatro Experimental do Negro (TEN), pelo qual foi convidado a escrever uma peça. Dessa proposta surgiu, então, Além do rio que acabou sendo escolhida por Abdias do Nascimento para representar o Brasil no Festival Mundial das Artes Negras, em 1966, no Senegal. Além da atuação do grupo, a temática da peça, por si, justificava a sua participação, já que a obra tem como tema o reencontro com a identidade. Apesar de acontecer de forma trágica, esse retorno simboliza a libertação da protagonista de uma escravidão psicológica à qual muitos negros estão sujeitos ao se deixarem acorrentar aos padrões impostos pelo ideal de branqueamento. As águas que lavaram de Jinga suas raízes negras, inclusive seu nome, ao levarem seus filhos louros (símbolo do seu branqueamento) devolvem suas raízes, deixando-a livre para voltar a ser negra e assumir sua raça, sua identidade e a sua cultura.

Essa reconstrução da identidade, tal como focada na peça, tão coerente com o movimento da négritude 4 e a importância inegável da representatividade do TEN naquele período como "única voz a encampar consistentemente a linguagem política da negritude, no sentido de priorizar a valorização da personalidade e cultura específicas ao negro como caminho de combate ao racismo" (Nascimento, 2004, p. 218) não foram suficientes para que o projeto de encenação da peça pudesse ser aprovado para a participação no evento realizado no Senegal.

O festival era um acontecimento patrocinado pela UNESCO, organismo intergovernamental, e as gestões para a participação das delegações eram feitas através de canais oficiais. O governo brasileiro desmereceu o trabalho do TEN como manifestação de arte negra digna de patrocínio para participar do evento (Nascimento, 2004, p. 218).

Foi enviado, então, um grupo "de capoeira" (Almeida, 2010, p. 87) ao invés da peça. Esse acontecimento deixou a montagem da peça em suspenso, sendo o texto, pelo que se sabe, inédito na cena teatral brasileira até os dias atuais.

Mas o texto teatral, publicado no livro Drama para negros e prólogos para brancos, organizado por Abdias do Nascimento, nos permite refletir sobre a proposta estética presente nessa dramaturgia de um Teatro Negro, através de uma inversão de valores no que diz respeito à temática, composição de personagens e linguagem construindo ainda uma relação com o ritual, musicalidade e estrutura cíclica tão presente na cultura negra.

\footnotetext{
${ }^{4}$ Négritude - movimento político-estético protagonizado pelos poetas antilhanos Aimeé Césare e Léon Damas e pelo Presidente do Senegal, poeta Léopold Senghor (Nascimento, 2004, p. 218).
} 


\section{A composição de personagens}

Uma questão perseguida pelo teatro negro, desde a formação do Teatro Experimental do Negro no Brasil, foi a necessidade de levar para a cena o protagonista negro, negando a restrição da presença do negro apenas aos "papéis secundários, folclóricos ou obscenos" (Semog, Nascimento, 2006, p. 123).

Em Além do rio o negro sai desse lugar secundário ou folclorizado e ganha voz, levanta suas questões, recuperando retalhos da sua história, erra e acerta, como todo ser que, sendo humano, está a todo tempo sujeito a falhas. Não há uma construção benevolente com as personagens negras; estas não são criadas numa única perspectiva, sendo totalmente boas nem as brancas, totalmente más. Há inclusive uma característica bastante híbrida na construção das personagens, estratégia consoante com à mistura do povo brasileiro. Lateja no mesmo ritmo o desejo de ocupar o lugar do outro (tão imposto ao negro que era estimulado pelos ideais de branqueamento). Esse processo funciona como uma espécie de lavagem cerebral que omite os verdadeiros valores das culturas negras, bem como torna o negro órfão de sua herança e, consequentemente, necessitado de acolhimento da cultura branca, mãe adotiva de bastardos.

Nessa peça as personagens negras são construídas com a mesma ênfase que às personagens brancas ou até mais, já que a protagonista Medea é negra. O número de personagens negras e brancas de maior destaque na peça é bastante equilibrado, sendo quatro negros (Jinga (Medea), Ama, Batista e Serafim) e quatro brancos (Egeu, Creonte, Creusa e Jasão); as personagens secundárias são uma negra (Mucama) e três brancas (Sinhazinha, I Criança e II Criança - filhos de Medea); os coros que transitam pela cena ou apenas são ouvidos constituem-se em um coro de brancas (Lavadeiras I, II, II) e três coros de negros (vendedores, Enamoradas, Escravos negros de ambos os sexos).

Jinga (Medea) é a personagem central da peça - a africana que, por amor a Jasão abandonou sua terra, matou seu pai e irmão e entregou seu povo para a escravidão; Ao chegar ao Brasil, ela abandonou suas crenças e aceitou ser batizada pela igreja católica sob o nome de Medea. Face ao mito de Medeia e da tragédia de Eurípides, este nome adquiriu o significado de assassina, infanticida, mulher traída pelo marido e vingadora. É a vinda de Jinga para o Brasil e o seu novo batizado que a tornam uma Medea. Se Jinga, ao acompanhar Jasão, entregar seu povo e matar seu pai e seu irmão, afasta-se do que há de negro nela, ao matar seus filhos (metáfora das amarras que a prendiam ao domínio branco) ela faz o caminho de volta a sua negritude, abandona o desejo de se tornar branca, compreende o seu valor e é por ele que ela faz o caminho de volta, dessa vez, matando o que havia nela de ideal de branqueamento, num reencontro com suas identidades e memórias "esquecidas".

JASÃO

Ó filhos meus que nunca mais verei sorrir! 
MEDEA

E nem mesmo a sepultura dêles será tocada por tuas mãos, já os levaram as águas que não voltam nunca mais. Vão ao encontro da fonte eterna e da grande solidão, pois lá, a perder de vista, as águas do grande rio vão misturar-se às do mar.

JASÃO

E o rio será lembrado e será rio maldito por todos os que mais tarde ouvirem a sua história.

\section{MEDEA}

E o rio será lembrado e será rio sagrado. Suas águas rolando vão sempre dizendo que não há maior glória que a que se alcança em não se deixar vencer. Vai-te daqui para sempre, nada mais tenho a dizer

(Olavo, 1961, p. 231).

O retorno de Medea é representado por um ato sagrado de alcançar a vitória, de se recuperar, mas também por um ato extremo (a morte dos filhos), o que enfatiza a dificuldade de se desvencilhar das amarras psicológicas que constroem um cativeiro mais eficaz do que as senzalas cuidadosamente vigiadas por violentos capatazes.

A negra Ama que acompanha Medea foi também sua ama de leite na infância e, como pessoa mais velha, ela age como uma referência dos antepassados. É uma anciã que deve ser respeitada e que carrega o conhecimento de toda uma vida. A Ama tem visões, quando risca a areia do chão. Simbolicamente ela representa os anciões do povo africano, respeitados pela experiência que lhes permite ver além. Mesmo querendo resistir, Medea sabe que precisa respeitá-la. Essa mulher, que como um griot $^{5}$ de seu povo relembra os fatos, conta as histórias dos antepassados e mantém viva a herança dos seus. Ao mesmo tempo ela representa uma espécie de cobrança das responsabilidades étnicas e alerta sobre as consequências que cada ato da protagonista desperta.

O negro Serafim, o mensageiro que contará às lavadeiras sobre a morte de Creusa, na peça de Agostinho Olavo, ao receber um nome assume uma individualidade maior como personagem, sem com isso deixar de representar também uma função (o mensageiro) que persiste no sentido do seu nome. Serafim é um nome de origem hebraica e carrega o significado de Anjo Guardião. A apropriação do nome é literalmente uma tradução para o acolhimento do negro. Mensageiro e guardião da desgraçada notícia, Serafim ao mesmo tempo transforma o horror desse momento trágico em alegria, quando enfatiza a questão de que haveria uma recompensa para quem encontrasse e entregasse Batista, o responsável por levar o colar a Creusa.

Sua Mercê o nosso bom capitão, já deu ordem para que tragam o Batista à sua presença, pois quer saber de onde veio o colar. Dá uma bôlsa de dinheiro e uma carta de aforria para aquêle que o prender. E todos querem agarrar Batista para ganhar as duas coisas mais gostosas que todo mundo quer ter: moedinhas de ouro e liberdade de viver. Até que para nós foi bom, não acham? Vosmicês me dão licença? Até mais ver (Olavo, 1961, p. 224).

\footnotetext{
5 "Tem-se notícia da existência dos griots desde o século XV. Tradição comum na África Ocidental, o griot é uma pessoa que através da oralidade tem a função de guardar/recontar e lembrar toda a história de uma família e/ou grupo.
}

Essa função é passada por gerações de pais e filhos" (Bernat apud Lima, 2010, p. 238). 
Serafim anuncia, ao mesmo tempo, a desgraça que tirou a vida da jovem noiva e a boa nova para os negros que podem conseguir sua alforria.

O mulato mudo Batista, que transita entre os brancos e negros, tanto na cor, quanto nos serviços que presta, é o empregado de Jasão que, diante de Medea, se faz de parvo e omite o noivado do patrão. Simultaneamente, será o responsável pela entrega do presente envenenado à filha de Creonte. Batista é o que mais se aproxima das personagens negras folclorizadas, construídas pela dramaturgia brasileira até então. A sua descrição aponta para algumas questões. Seria ele paradigma do branqueamento forçado?

Rubrica: Batista, o servidor de Jasão, aparece no fim da margem pedregosa. Vem dançando ao som do maracatu que se ouve ao longe. Pés descalços, calção listado de amarelo e azul, blusa aberta até a cintura, grande chapéu de palha, é o autêntico molecote daquela época. Mestiço, nascido dos amôres sensuais do português com a escrava favorita, tem as qualidades e os defeitos dos brancos aventureiros e dos negros sofredores. Bom de coração e, ao mesmo tempo, venal e esperto, quer sempre dinheiro e tudo faz para consegui-lo. Nunca se sabe se é parvo, ou se por cálculo se faz assim. Ágil e esbelto é todo um feixe de gestos e atitudes... (Olavo, 1961, p. 215).

Batista é uma mistura do branco e do negro. Essa característica estará tanto na cor da pele quanto em suas ações, como o próprio autor afirma na descrição. A vida de Batista está em perigo a partir do instante em que entrega o presente de Medea; mesmo assim, ele a procura para narrar a morte de Creusa. A narração muda (corporal) de Batista, ao comunicar algo tão importante, remete, no nosso ponto de vista, à privação dos negros da linguagem verbal e à construção de novos discursos tão presentes na cultura negra, que vai se utilizar de diversas estratégias (música, dança, rituais etc.) para resistir ao apagamento e preservar sua comunicação e sua herança.

Coros de escravos vendedores de frutas, flores, pássaros e tripas e as enamoradas (três escravas dançarinas) irão passar pela cena, marcando o cenário de desventuras a que foram atirados os negros, muitos deles pela própria Medea. Essas personagens, diferenciando-se dos coros gregos, não apenas comentam as ações, mas intervêm nelas ao rejeitarem Medea, recusarem-se a lhe vender algo ou falar com ela. Há temor e respeito por Medea, afinal ela era para o seu povo uma "chefe do terreiro", mas a revolta pelo destino imposto a eles pelas ações de Medea faz com que a rejeitem claramente, mesmo que não possam agir contra ela.

O som dos tambores ao fundo, que, em alguns momentos, surge mais forte e em outros desaparece, representa um grupo de negros refugiados em um quilombo, clamando pela presença de sua rainha negra: Jinga. Eles exercem sobre a personagem uma influência de atração e repulsa. Medea canta e dança num transe provocado pelo chamado dos tambores 
MEDEA (Cantando e dançando)

Anagogô... auê... auá,

Anagogô... auê... auá.

Ogun já chegou,

Ogun vai baixar.

(da floresta, responde o côro dos negros)

Anagogô... auê... auá,

Anagogô... auê... auá.

Ogun já chegou,

Ogun vai baixar.

MEDEA (parando bruscamente e lutando contra a atração do ritmo)

Não. Não quero ir. Não hão de me levar. Mas por que me chamam assim?

Por que não param de tocar? (Olavo, 1961, p. 204).

Se por um lado os vendedores se recusam a falar com Medea, por outro, ela também se nega a ouvir o chamado dos negros nas florestas e tenta resistir, luta contra a necessidade de atender ao chamado do seu povo, da sua raça, prendendo suas vontades aos desejos do branco que a conquistou.

Essa presença de um coro negro fora da cena, além de representar o chamado da raça que clama por Medea, amplia ainda mais nossa dimensão das personagens negras presentes na peça. Elas invadem a cena, seja visual, ou apenas sonoramente, enfatizando a enorme presença e influência dos negros nas terras brasileiras desde então.

As personagens brancas surgem como primeira imagem da peça: um coro de lavadeiras, personagens que não têm nome próprio, são chamadas de I, II e III lavadeira. Como o coro das peças gregas, elas comentam a cena, dão-nos as informações sobre os acontecimentos e emitem a opinião sobre a situação, prenunciam a descoberta de Medea sobre o noivado de Jasão e aguardam ansiosas a reação da negra traída. As lavadeiras a princípio representam a imagem construída sobre o negro aos olhos dos brancos nesse período, manifestando forte preconceito através da maneira de contar a história, da forma de apresentar os fatos sobre a vinda de Medea para o Brasil e seu jeito de viver, deixando entrever o olhar discriminador sobre o negro, suas características físicas e religiosidade.

Ao longo da peça, as Lavadeiras vão percorrer um caminho de aproximação e identificação com Medea que, aos poucos, propõe uma desconstrução das diferenças impostas pelo preconceito racial.

O próximo personagem branco a surgir na cena é Egeu, um velho que chega carregado de presentes para Medea, depois de longas viagens à procura de um remédio que o ajude a ter filhos. Ao se recusar a ajudar Egeu, Medea desperta a fúria do viajante, que, para se vingar, conta sobre o noivado de Jasão com Creusa a filha do capitão Creonte. Depois de vingado, Egeu desacredita dos poderes de Medea, afirmando que se ela fosse realmente tão poderosa não teria perdido Jasão.

EGEU - Começo a duvidar do valor dos teus filtros. Tu mesma, infeliz, fostes abandonada e só sabes suplicar. Onde estão os teus feitiços, se nada podes fazer?

MEDEA - No meu amor por Jasão, nunca usei de mandingas nem sequer de can- 
jerês (Olavo, 1961, p. 216).

Egeu parte infeliz para suas terras por não conseguir o remédio para ter filhos, mas ao mesmo tempo, se sentindo vingado daquela que lhe negou auxílio, ao vê-la também em sofrimento.

Creonte é branco, capitão com grande poder de mando sobre as terras brasileiras e senhor de muitos escravos. Para proteger sua filha, ele expulsa Medea da ilha, sob a ameaça de vendê-la como escrava. Como a Medeia euripideana, a Medea de Olavo pede a Creonte apenas um dia para preparar sua partida, mas, diferenciandose da grega, que por ordem de Creonte deveria partir com os filhos e precisaria pedir a Jasão para que ficasse com eles, a Medea brasileira é avisada por Creonte de que não poderá levar os filhos, pois esses são brancos, "alforriados na pia" e "Só pertencem ao pai" (Olavo, 1961, p. 218). Ao concordar com a permanência de Medea mais um dia, Creonte comete o mesmo erro do personagem grego, deixando espaço suficiente para que a vingança seja concretizada.

Creusa, filha de Creonte, é uma mocinha mimada que ansiava por um casamento, inclusive já tendo buscado os trabalhos de Medea para auxiliá-la na conquista desse intento. Para ela conquistar Jasão, mais do que por amor, seria também uma forma de se vingar da "macumbeira", que não sabia reconhecer seu lugar e a esnobou sem ao menos atender o seu pedido.

Jasão, poderoso vendedor de escravos, ao conquistar Medea facilitou sua empreitada no domínio do povo negro, que, confiando em Medea, a seguiu, sem saber que se encaminhava para o cativeiro. Jasão vive durante alguns anos com Medea e, quando resolve se casar com Creusa, a filha do capitão, não procura a consorte para Ihe dar qualquer satisfação, deixando-a ignorante do seu destino, o qual será descoberto por confissão de terceiros e pelas ameaças feitas por Creonte, que aparece na ilha para expulsá-la. A única cena em que Jasão aparece com a protagonista é no final, quando confronta Medea após o assassinato de Creusa e acaba por descobrir a morte dos filhos também. Ao excluir de sua reescritura as duas cenas da peça grega em que Jasão confronta Medea antes da morte da noiva e dos filhos, Olavo diminui a importância dessa personagem na peça, construindo-a muito mais pelo que dizem dela do que por suas ações em cena.

Agostinho Olavo destaca a importância das personagens negras da obra sem excluir as personagens brancas, mas altera os valores discursivos ao dar ênfase à fala do negro que, na personagem Medea especificamente, se inicia como um discurso colonizado, aos poucos, vai reencontrando sua voz, assumindo-se como indivíduo negro. $O$ autor também cria paralelos entre alguns personagens brancos e negros: alguns não têm nome e formam coros para representar tanto os sentimentos racistas através das lavadeiras brancas, ou mesmo o rancor, a revolta e a crença dos negros, através dos vendedores ou do coro que clama por Jinga (Medea) nas matas.

\section{Apropriação da linguagem}

A releitura em si também já é a apropriação de uma linguagem. Agostinho Olavo mantém grande fidelidade estrutural à tragédia grega de Eurípides, porém quanto 
mais ele se aproxima da peça original, mais ênfase dá aos elementos que caracterizam seu distanciamento. A Medeia grega se vinga da traição que desonrava a rainha bárbara; a Medea brasileira se desprende das amarras que a prendiam à escravidão a que se submetera por amor. Medea, em sua essência, permanece Jinga, e ao se reencontrar, dissimulada numa aparente prisão à cultura branca (numa metáfora sintetizada na estrutura da tragédia grega), reencontra os caminhos de libertação.

Para o teatro, como para o plano concreto da existência, o procedimento é o mesmo. Expatriados e escravizados, os povos negros adotam, como uma primeira estratégia de sobrevivência, a dissimulação. [...] Nas representações dos negros uma coisa nunca é o que parece para o branco. Nessa primeira etapa os negros aprendem formas mais complexas de metamorfose, sempre à procura de uma linguagem que restaure a origem, vingue a história e realize a igualdade (lima, 1995/1996, p. 260).

Tomar como ponto de partida a Medeia de Eurípides é uma forma dissimulada de atrair olhares para os elementos presentes na cultura negra e de entender o grego como um substrato comum do negro e do brasileiro. A impressão de uma espécie de "obediência e rebelião" na adaptação de uma obra universal faz com que ela atinja os olhares dos mais diversos espectadores antes de ser excluída pelo preconceito.

Em Além do rio, o texto das personagens negras é bem elaborado, posiciona o indivíduo negro, questiona valores e poderes e coloca em primeiro plano um discurso tantas vezes camuflado ou estereotipado. Além disso, numa perspectiva quantitativa, o texto das personagens negras é mais longo que o das personagens brancas, numa inversão do poder da fala. Seja nos diálogos de Medea com Jasão, Creonte ou Egeu, é sempre ela quem terá as falas mais longas. Suas réplicas dão espaço à fala negra, numa tentativa de dar voz ao negro, dar espaço para que ele se coloque de forma real, como ele se vê e não através do filtro do olhar do branco.

Ao constituir-se intencionalmente como arte o Teatro Negro será uma escritura polimórfica, associando à teatralidade singular africana o signo verbal do discurso dominante. Nessa nova escritura cênica a língua do branco é resignificada para desvelar ao invés de ocultar o negro. A apropriação é audaz ou sub-reptícia (Lima, 1995/1996, p. 258).

O discurso do negro é destacado e ganha importância nesse texto, não só pela extensão das falas, mas também pela construção do discurso da personagem, a ênfase no que é dito, no seu posicionamento frente às situações enfrentadas. O discurso das personagens brancas nessa peça também é essencial, já que será muitas vezes a mola propulsora para o desencadeamento de conflitos que têm como foco a questão racial.

O branqueamento do discurso da personagem negra aparece logo no início da peça, na voz da própria Medea, que utiliza a sintaxe e o vocabulário do branco português. Desse modo, ela afirma sua submissão ao domínio de Jasão e o seu desejo de ser libertada das amarras que a prendem a sua raça.

\section{MEDEA}

São meus filhos sim, são meus filhos; são dois punhais afiados para cortar as cordas que me prendem a minha raça. Dêste corpo prêto e duro, como o chão 
de minha terra, saíram dois leõezinhos dourados e me ligaram a outra gente. São a luz da minha sombra, os meus filhos de Jasão. E quando os tenho nos braços, quando a tarde já começa a desmaiar, sinto-me branca como a espuma do mar (Olavo, 1961, p. 208).

Ao ser abandonada por Jasão e comunicada, por Creonte, de que deve partir sem os filhos, Medea se vê lançada no vazio, deixada a orbitar entre o universo pretendido e aquele do qual se isolou por escolha, ao se deixar escravizar pelo homem amado. Jasão e os filhos formavam o único elo dela com o mundo branco. "Os filhos do casal são uma imagem especular do pai - são brancos e louros - e uma extensão da prisão cultural e racial de Medea, pois reproduzem, na cor, o seu próprio desejo especular de ser branca" (Martins, 1991, p. 135). O marido branco e depois os filhos brancos são símbolos do branqueamento de Medea. Quando os conquista, ela se aproxima mais desse ideal branco, tornando-se, também, ao menos ideologicamente, um pouco branca. Ao perder Jasão, Medea se vê sem saída e trava a luta mais difícil: a do retorno às suas raízes. Para isso, se o elo com Jasão já está cortado, o cordão com os filhos precisa ser rompido por ela mesma.

A passagem reversa de Medea a Jinga não é instantânea. Há uma suspensão, um espaço intermediário a ser superado pela protagonista, um novo rito de iniciação a ser executado. Entre as matas, onde se encontram os negros fugidos, e a ilha, fronteira simbólica dos níveis da realidade entre os quais se posta Medea. A travessia do rio é o desafio da heroína. Um ritual de passagem que pode revitalizá-la ou destruí-la. Sua solidão e o silêncio dos atabaques marcam o momento de suspensão, de desafio. Sabendo serem os filhos o último elo significante de sua ligação com uma situação que quer deslocar e romper, Medea os encaminha para as águas. Prevendo que as crianças não sobreviverão à passagem. A morte dos filhos simboliza um sacrifício pessoal de Medea e uma ruptura da rede de subordinação que a prendia. Seu gesto trágico é fruto de uma decisão pessoal, irreversível e inexorável. Como pharmakós, remédio e veneno, a morte dos filhos rompe, metafórica e literalmente, a prisão da mãe. Simultaneamente punindo Medea e purificando Jinga (Martins, 1991, p. 138).

O léxico de Medea começa então a mudar: "Ainda tocam o ponto. Ainda precisam de mim. Ainda sou rainha. Ainda sou preta e orixá" (Olavo, 1961, p. 231). O discurso do embranquecimento será desconstruído e toma seu lugar a reafirmação de uma identidade negra.

Algumas cenas darão ênfase ao contraponto do discurso, como a cena inicial, em que são intercalados os diálogos entre as lavadeiras e entre Medea e a Ama.

\footnotetext{
AMA

Para elas vosmicê não passa de uma escrava fugida.

São brancas, não se esqueça.

MEDEA

Que me importa! Sou rainha. Elas sim, são escravas que vivem sempre lavando tudo que os brancos sujarem. Têm inveja de mim. Sou a mulher do guerreiro mais valente de cem milhas em redor da vila de S. João. Têm inveja, porque Jasão trouxe Medea e Medea vive só para Jasão.
} 


\section{LAVADEIRA}

Fala do amor do branco.

III LAVADEIRA

Não sabe ainda.

I LAVADEIRA

Bem feito. Vai pagar por seus pecados.

II LAVADEIRA

Coitada! Tenho pena, mas não posso deixar de rir (Olavo, 1961, p. 206).

O contraponto entre os dois discursos vai destacar o preconceito das lavadeiras com Medea e sua relação com o branco; ao mesmo tempo, mostra a negra Medea como uma mulher que reconhece o seu valor, apesar da submissão que seu amor a Jasão lhe impõe.

As lavadeiras têm um discurso claramente racista, mas, ao longo da peça, o autor vai deslocando esse discurso a ponto de as lavadeiras, a partir de determinado momento, se compararem a Medea. O abandono de Medea torna-se um problema feminino da submissão das mulheres em relação aos homens e da relação de mães e filhos - num âmbito mais abrangente, problemas de qualquer ser humano.

IIII LAVADEIRA

Estúpida! Esqueceu de que os homens, por interesse ou razão, colocam-se sempre antes de tudo (Olavo, 1961, p. 207).

$[\ldots]$

II LAVADEIRA

Pensei que pudesse rir, mas creio que vou chorar.

III LAVADEIRA

Coitada! Uma tristeza é o amor para tôdas as mulheres

(Olavo, 1961, p. 224).

[...]

AS LAVADEIRAS (em coro)

Dor de branco... dor de negro... ela é sempre a mesma dor

(Olavo, 1961, p. 226).

$[\ldots]$

III LAVADEIRA

Medea, por piedade! Também somos mãe, mulher. A nossa cor não importa (Olavo, 1961, p. 228).

O discurso racista vai se desconstruindo e ao final da peça as personagens, que antes zombavam de Medea e a ignoravam, falam com ela na tentativa de salvar os filhos de Medea; finalmente, vencidas pela negativa de Medea, vão embora diante de tanto sofrimento. A percepção de que a cor não importa só acontece no momento da concretização do ato trágico, ou seja, quando é tarde demais. Nossa interpretação aponta para as consequências inequívocas (isto é, em grego, ananke, a necessidade) da prática do preconceito. É hora da katastrophé, instaura-se todo mal gerado a partir dele. 
O subtexto também é uma forma de discurso e tem forte influência na escrita do teatro negro. Em Além do rio, Medea comete atos terríveis como o de matar seu pai e irmão, a filha de Creonte e finalmente os dois filhos, quando os envia para o mar; todavia, nenhum dos seus atos torna a personagem uma vilã. Olavo não está falando da negra Medea como uma criminosa, capaz de fazer coisas que os brancos não fariam, como o próprio Jasão irá acusar-lhe

\section{JASÃO}

Fui um louco em pensar que de uma terra de bárbaros podia trazer uma mulher para mim. (Ri desesperadamente) uma mulher que depois de haver traído sua tribo, depois de matar pai e irmão, deita-se nos meus braços e troca juras de amor. Tu és o gênio do mal, que os deuses enviaram contra mim para pagar pelos escravos que fiz acorrentar nas praias da África, nenhuma mulher branca ousaria fazer o que fizeste (Olavo, 1961, p. 230).

O autor se refere ao negro como indivíduo que necessita resgatar sua negritude e se desvencilhar do domínio branco, do desejo de branqueamento imposto pela sociedade. A negra que mata seus filhos na peça é como as escravizadas que matam para salvá-los do domínio dos brancos. Se Medea, no início da peça, tenta se desvencilhar dos laços com seu povo, matando pai e irmão, entregando os de sua tribo à escravidão e submetendo-se ao domínio branco; se ela abre mão de seu próprio nome, de sua crença, abandona sua responsabilidade como mãe de santo, vê nos filhos brancos a possibilidade para se tornar um pouco branca, no final da peça ela quebra os laços que a ligam ao branco ao assassinar os filhos (metáfora da libertação do domínio do branqueamento), reassume seu nome africano Jinga, indo em busca de seu povo, e aceita sua posição de dona do terreiro nos quilombos onde os tambores clamam por sua presença para que os orixás possam baixar.

Nos dizeres de Cândido, com a sua Medeia, Eurípides denuncia o perigo de as mulheres dominarem alguns conhecimentos (como a arte da feitiçaria) com mais propriedade que os homens na Atenas clássica.

[...] o poeta utiliza o espaço do teatro de Atenas, através da personagem Medéia, para fazer uma denúncia, alertando para a emergência de antigos saberes integrando novas práticas sociais como o uso do conhecimento mágico das ervas e filtros para atender desejos individuais. $\mathrm{O}$ uso das práticas mágicas das ervas e raízes tanto podia atender às necessidades de medicamentos para curar as doenças femininas, quanto ser usado como veneno para efetuar uma vingança. Medéia com a sua sophia expõe a ambiguidade de um saber que poderia ajudar um amigo com os seus benefícios, mas poderia ser fatal e destruir os inimigos (Cândido, 2006, p. 32-33).

Esse domínio poderia deixar os homens mais suscetíveis aos poderes das mulheres, que seriam, assim, detentoras de um saber pouco controlado por eles, podendo elas também tornarem-se menos submissas. Com a Medea brasileira, Agostinho Olavo fala por um viés positivo, de uma negritude que precisa ser assumida e da necessidade de construção do seu espaço. A mãe grega mata pela honra, para cortar a descendência; a mãe negra mata por necessidade de liberdade, para salvar os filhos e recuperar suas raízes. 
O teatro negro incorpora ao seu enunciado três elementos constantes: a lembrança da cultura africana, a história da escravidão e do racismo e a desconstrução de imagens perversas do negro. Entretecidos pelo componente original - a teatralidade afro -, as criações do Teatro Negro mantêm um componente lúdico por onde o espectador pode penetrar para sentir-se co-produtor de um discurso comunitário.

Não se trata contudo de um jogo prazeroso, onde prevalece a fruição descompromissada. Em todos os exemplos estudados a abertura do jogo cerca temas graves, como as feridas profundas provocadas pelo racismo. A isso se alia a exaltação das formas e valores obliterados pelo olhar de cultura dominante. Tendo de cumprir a tarefa de reafirmar uma identidade ameaçada, o jogo cênico assume, invariavelmente, a fisionomia de um combate ritual (Lima, 1995/1996, p. 259).

Matar o filho é uma metáfora dessa reafirmação da identidade. Olavo constrói um paralelo entre a tragédia grega de Medeia e a história do negro no Brasil, remetendo-nos a tantas histórias vividas pelos negros nessas terras. Como exemplo, podemos citar a história da escrava Justina que matou os filhos por acreditar que seria separada deles.

De acordo com os depoimentos, Justina, que dormia com as três crianças, as retirara à noite, pela janela, afogando-as no tanque perto de casa. Em seguida, voltara ao quarto e ali tentara matar-se, cortando a própria garganta. Ferida, teria saído novamente pela janela, dirigindo-se à casa de João Claudino, carpinteiro e sitiante, que se negou a matá-la e tentou convencê-la a voltar para casa. Ela fugiu mais uma vez e ficou embrenhada no mato por oito dias, quando finalmente foi presa, com ferimento na garganta infeccionado. Justina viveu o suficiente para ser condenada a 42 anos de prisão simples (Castro, 1997, p. 348).

A Medeia grega mata os filhos com um punhal, mas a Medea brasileira, ao modo da escrava Justina, mata os filhos afogados. A justificativa é diferente: não há ciúme no caso de Justina, mas há essa "dimensão de mercadoria" (Castro, 1997, p. 350) que Creonte irá aplicar a Medea quando a ameaça, dizendo "se não partires, serás posta a ferros e vendida como uma escrava qualquer" (Olavo, 1961, p. 217). A história dessa escrava que se viu ameaçada da separação dos filhos é uma amostra de um contexto social, ao mesmo tempo que é a história de Justina, é a história de tantas outras negras escravizadas. Suas semelhanças com a reescritura de Olavo por certo não serão simples coincidências, como a Medea de Olavo, essa Mãe é corrompida pelo preconceito que faz com que ela cometa esse ato. Ambas vítimas do preconceito que deixa marcas, vazios e dores em todo indivíduo que o sofre na pele a cada dia e precisa persistir na luta contra ele e na construção de uma verdadeira democracia racial.

Abandonada a assimilação, a liberação do negro deve efetuar-se pela reconquista de si e de uma dignidade autônoma. O esforço para alcançar o branco exigia total autorrejeição; negar o europeu será o prelúdio indispensável à retomada. É preciso desembaraçar-se dessa imagem acusatória e destrutiva, atacar de frente a opressão, já que é impossível contorná-la (Munanga, 2012, p. 43).

O discurso branco, que fazia com que Medea rejeitasse tudo o que havia de negro nela, é desconstruído quando ela ataca seus opressores e resiste à dominação 
em favor da reconstrução do discurso negro.

Esse discurso negro pode ser acionado também pelo léxico, como podemos verificar em Além do rio: o autor insere palavras, termos e nomes herdados dos idiomas africanos. Ao propor para a cena uma nova sonoridade e causar um estranhamento, Olavo exige que nos atentemos para compreender o seu significado e nos propõe o contato com alguns sentidos ignorados.

\begin{abstract}
Assim, a afro-brasilidade tornar-se-á visível a partir de uma discursividade que ressalta ritmos, entonações, opções vocabulares e, mesmo, toda uma semântica própria, empenhada muitas vezes num trabalho de ressignificação que contraria sentidos hegemônicos na língua. Isto porque, bem sabemos, não há linguagem inocente, nem signo sem ideologia (Duarte, 2008, p. 18).
\end{abstract}

Ao trazer para a cena diversas palavras africanas, nomes de lugares, pessoas, crenças etc., já utilizados ou não no português brasileiro, o autor permite-nos uma reflexão sobre a apropriação desses termos.

Os sentidos das palavras irão se modificar, dependendo do emissor, já que muitas vezes serão tratadas de forma pejorativa pelas lavadeiras, por exemplo. Originárias de campos semânticos diferentes, o autor insere palavras relacionadas:

à religiosidade africana: mandinga, canjerê, macumbas, mezinhas, ponto, candomblés, búzios, orixás, mãe de santo e feiticeira; a saudações: Olorum modupé; a instrumentos musicais: tambores, atabaques, tantãs, marimbas e agogôs; a danças e músicas: Lundu, Maracatu; a localidades: Costa d'Ouro; aos nomes de algumas etnias trazidas para o Brasil como escravizadas: Monjola, Congo e Moçambique; a nomes próprios: Jinga (nome de Medea antes de ser batizada no Brasil), Aétes (pai de Jinga, grande chefe de uma tribo que descendia do sol) e Suana Mulopo (irmão de Jinga).

A presença de todas essas palavras no texto teatral permite que o leitor/espectador tenha contato com esse universo sonoro e semântico que chega ao Brasil com os negros e passa a fazer parte de uma linguagem afro-brasileira como parcela das influências trazidas da África com a escravização.

\title{
4. Ritual e musicalidade
}

Se a linguagem verbal muitas vezes será usada pelo branco personagem para discriminar e enfatizar o preconceito da sociedade branca, que buscava rebaixar tanto a imagem, quanto o valor do negro, por outro lado será marcante, talvez até em maior grau, a linguagem não verbal, já que era um discurso de afirmação dos negros, que não puderam calar completamente.

$\mathrm{Na}$ expressão da cultura branca dominante a linguagem verbal é o instrumento privilegiado para segregar e destruir. Vocábulos, expressões e situações estereotipadas estigmatizam, na dramaturgia dos autores brancos, a cultura e o 
tipo físico africanos. A esse discurso a cultura afro responde através de signos não-verbais. Por meio do canto, da dança, do mascaramento dos rituais religiosos e manifestações cênicas os negros, no período escravagista, resistem e preservam a memória da sua identidade cultural. São estes mesmos elementos de uma linguagem espaço-temporal que se transferem, respectivamente nos séculos XIX e XX para escrita dramática nos palcos brasileiros... (Lima, 1995/1996, p. 257).

\title{
Essa presença não verbal estará na peça através das músicas, danças e do sin- cretismo religioso. Segundo Evani Tavares Lima,
}

Para Traoré (1972), o modo como se dá a presença dos ritos e cerimoniais no teatro tradicional africano é muito similar à maneira como acontecia no antigo teatro grego, à época dos festejos do deus Dioniso. Entretanto, ambos acabaram por seguir orientações distintas: enquanto na Grécia o drama ganha autonomia e se distancia do aspecto religioso; na África, esta religiosidade no drama permanece conectada ao elemento ritual. E na Diáspora, essa inspiração ritual também aparece nas mais diversas expressões negras brasileiras, sejam elas brincantes e/ ou espetaculares: a capoeira angola, o tambor de crioula, os congos de reis e os reisados, por exemplo. Essas e outras expressões da maneira como são reinventadas e re-configuradas por conta das naturais fusões da nova situação geopolítica cumprem (vem cumprindo) a função de não nos deixar esquecer. De fazer renascer em nós aquilo que nos foi expropriado: o pertencimento. Aquilo que nos faz reconhecer como parte de um grupo étnico ou cultural pela identificação com seus valores, [...] (Lima, 2010, p. 251-252, grifo da autora).

\begin{abstract}
O teatro negro vai se apropriar da herança do teatro tradicional africano e grego através da relação com a repetição configurada tanto no caráter ritual quanto no caráter espetacular (já que o teatro guarda esse caráter de uma arte da repetição), auxiliando o processo de identificação do indivíduo negro.
\end{abstract}

Ao se repetir, se reedifica, se fortalece, e se mantém referenciais importantes para aqueles partícipes do ritual/espetáculo. Com sua ação ele fortifica e valoriza a identidade negro-descendente, tantas e, tantas vezes, injustamente, maculada. Assim, segue-se a máxima: "Repetir é lembrar!" Através da repetição, da recorrência a um lugar de encontro de todos, se vivifica o lugar do eu-referencial (Lima, 2010, p. 252).

E essa repetição funciona como um processo de recuperação da noção de "pertencimento" tanto para o espectador quanto para o ator, que vai se conscientizando de sua identidade a cada momento que repete/lembra de si nesse ritual cênico.

A presença da religiosidade afro-brasileira na dramaturgia do teatro negro permite, além da identificação, a percepção do caráter sincrético que é marca da cultura negra brasileira. Conforme salienta Evani Tavares Lima,

Para Leda Martins (1995), os efeitos resultantes da associação desse teatro com o ritual, ecoam nas configurações, construções imagéticas e elaborações sígnicas das performances desse teatro apresentando-se em forma de dialogismo - a fala é coletiva, busca eco no outro. A autora destaca a multiplicidade de ritmos que emerge nesse teatro inspiradas no batuque dos terreiros, das igrejas, dos maculelês, cordões e afoxés; dos cantos, cantigas, desafios, rezas, louvações, pregões, avisos e sotaques apropriados por esse teatro. A multiplicidade de signos varia conforme o ponto de vista: como o mito de Exu (o senhor da duplicidade, o men- 
sageiro da liturgia dos orixás) que confronta duas verdades, como a capoeira que é luta e dança, a arte que também pode ser religião. A dupla fala como a metáfora, a ironia, a paródia, como formas de lidar com o outro em situações adversas e/ou cumplicidade (Lima, 2010, p. 253-254).

Agostinho Olavo, em Além do rio, ao colocar em um mesmo espetáculo, paralelamente, os ritos africanos e o batismo católico, vai dar ênfase a essa mistura, marca da cultura negra e consequentemente da cultura brasileira, na qual é recorrente o cruzamento entre as religiões e a mistura das celebrações.

Jinga (Medea) é mãe de santo do candomblé na África; quando chega ao Brasil, é batizada como Medea e obrigada por Jasão a deixar de lado sua religião. Medea não faz mais os "trabalhos" que aprendeu com sua religião; no Brasil é procurada por muitos brancos católicos (inclusive por Creusa, filha de Creonte), mas se recusa a fazer as "mandingas e canjerês" que conhece.

Algo que não é dito, mas também fica presente como um discurso oculto, é a necessidade que todas as personagens, brancas ou negras, têm de solicitar o auxílio dos conhecimentos de Medea. Todos discriminam sua herança religiosa, mas procuram a ajuda nos conhecimentos da "feiticeira" sempre que precisam. Quando os negros passam vendendo seus produtos, uma das lavadeiras brancas quer comprar um ramo de arruda muito usado para benzeção. Essa questão aparece, assim, todo o tempo, discretamente, mas sem abrir mão de seu espaço.

A musicalidade também vai ter esse caráter sincrético. Na festa de noivado de Jasão e Creusa há a mistura entre uma comédia pastoril e o som do Maracatu e do Lundu. O pastoril normalmente é representado nas festas natalinas em comemoração ao nascimento de Jesus; já o Maracatu é um folguedo estritamente ligado à africanidade e tem como época principal o carnaval; o Lundu, sendo uma dança originalmente africana tem como característica a mescla dos espaços: "Além dos terreiros de batuque adentra também as salas das residências mais abastadas [...] passou a ser requisitada em festas e saraus domésticos. Eram os batuques dos negros, juntamente com mestiços e brancos, que passavam pelo processo de cancionalização" (Bezerra Filho, 2008, s/n). Na peça, essa mistura é clara e enfatizada todo o tempo, mas principalmente na cena do casamento.

... o canto esconde uma senha, a cerimônia religiosa se disfarça de festa, a luta se traveste em dança e, por fim, o texto teatral subverte os valores e expressões verbais com que o branco dissimula ou denigre a identidade do negro. [...] manifesta-se primeiro a teatralidade e, em seguida, um esforço de reversão dos atributos negativos em positivos (Lima, 1995/1996, p. 258).

A festa nesse momento é tida como algo positivo, não é julgada pelos brancos. A própria Creusa, personagem preconceituosa e arrogante, desce ao terreiro para dançar com os negros na alegria pela expulsão de Medea da ilha e da concretização do seu noivado.

Tomando como referência essa mistura de rituais e musicalidade, podemos levantar algumas questões a respeito das intenções do autor. O que Agostinho Olavo pretendeu colocar na peça, na festa de noivado de Jasão, uma comédia pastoril? Se o noivado é o que precede o casamento de Jasão e Creusa, e consequentemente a 
morte dos filhos de Jasão e Medea, tratar-se-ia então de uma ironia trágica? NNessa festa, a filha de Creonte morre envenenada e a concretização desse assassinato obriga Medea a cumprir seus planos de matar os filhos para salvá-los das mãos inimigas. A relação entre a mãe que dá vida ao filho por amor (Maria e Jesus - temática impressa na comédia pastoril) e da mãe que tira a vida dos filhos por amor (Medea e os filhos) se desdobra numa relação entre as águas que se derramam do ventre feminino para que o filho de Maria nasça e as águas que acolhem como um novo ventre os filhos de Medea.

A musicalidade é muito presente no rito e o rito na musicalidade, a ponto de, muitas vezes, não sabermos distinguir um do outro.

É recorrente na peça o ponto de macumba que Medea canta, dominada pelo chamado em alguns momentos e em outros totalmente entregue por ser o lugar seguro, do seu retorno ao seu povo, a sua crença, a sua raça.

O discurso dos tambores no meio das matas, que clamam por Medea, pela sua volta à raça, é um chamado que paira sobre a peça todo o tempo, variando ritmos, volume e intensidade, mas sempre presente. Até quando os tambores silenciam na cena final da peça, sua presença continua rondando, na chamada angustiada de Medea por sua raça, que clama para que voltem a tocar e deem a ela o caminho de volta ao seu povo.

\section{MEDEA}

As sombras já me rodeiam, calaram-se as vozes da mata, só me resta a solidão. Vozes, ó vozes, da raça, ó minhas vozes, onde estão? Não ouso cruzar o rio e tenho medo da ilha, de seu silêncio tão grande. Ó vozes da minha raça, ó minhas vozes, onde estão? Por que se calam agora? A negra largou o branco. Medea cospe este nome e Jinga volta a sua raça, para de novo reinar.

(Lentamente começam os atabaques, os tantãs e os agogôs a tocar um ponto de macumba. A floresta vai se iluminando de archotes. Vultos se recortam entre as árvores. São os negros fugidos, seminus, que numa macumba sangrenta festejam a volta de Medea a raça) (Olavo, 1961, p. 231).

Medea confirma a aprovação do seu povo quando ouve o toque do ponto de macumba e começam a surgir os negros, os companheiros que nunca desistiram dela e que a todo o tempo a chamaram de volta ao seu povo, a sua raça.

Os cantos populares, os pregões, as quadrinhas, a comédia pastoril e o terno vão alinhavar os caminhos que levam até o noivado de Jasão e Creusa. Além disso, marcam o hibridismo das culturas. Coelho, citando Abdias do Nascimento (2004, p. 214), afirma:

No caso da peça de Agostinho, além de tematizar a questão da discriminação racial o autor mostra uma perspectiva antropológica, ao colocar no palco, músicas e rituais não apenas de tradição africana, mas também do folclore português e ao destacar o problema do indivíduo cindido entre duas culturas, como observou Nascimento, "A dinâmica visual do espetáculo baseava-se nos cantos e danças folclóricas - maracatu, candomblé - complementadas pelos pregões dos vendedores de flores, frutos e pássaros. A fusão dos elementos trágicos plásticos e poéticos resultaria numa experiência de negritude em termos de espetáculo dramático..." (Coelho, 2005, p. 161). 
Essa variedade de musicalidade colhida da tradição oral e da cultura negra leva-nos a destacar ainda mais um elemento: a oralidade - tão presente nas culturas africanas, enfatizando o papel do griot, do contador de histórias. A herança nas culturas negras é passada oralmente dos mais velhos para os descendentes através de histórias contadas, muitas vezes musicadas, pelas danças e rituais. A música, aqui, não é apenas uma ilustração, mas traz informações que fazem com que a peça caminhe.

A estrutura cíclica presente nas crenças religiosas africanas irá influenciar a estrutura da peça Além do rio.

Para nós que acreditamos nos orixás, o ciclo é uma realidade transcendente. Não é apenas uma abstração, não é uma coisa puramente conceitual, abstrata; é um movimento concreto que tem uma relação direta com o ser, com a vida terrena e com a vida no Orum 6 , a vida transcendente, a vida que está além do nosso mundo real. O supra-real (Semog, Nascimento, 2006, p. 35).

Este caráter cíclico está presente em muitos espetáculos do teatro negro e é marca importante, pois dilata a ideia de travessia. Mais que deixar a África e vir para o Brasil, em Além do rio, a personagem central deixa seu povo, suas crenças e sua raça e passa toda a peça resistindo e, por fim, cedendo à atração de retornar. Essa volta não será para a África, mas para o seu povo, para a sua raça.

Medea é a representante de seu povo, a chefe do terreiro, não pode abandonar sua crença e nem os seus irmãos negros. A representante não pode se conformar e se deixar dominar; se ela luta, o povo lutará ao seu lado e sob o seu comando. Quanto mais se afasta deles, mais doloroso será o seu retorno. E a Ama avisa várias vezes a Medea sobre a importância do seu retorno. Medea é um "orixá" para seu povo. Quando ela diz isso, está se referindo ao respeito em um sentido sagrado, que os negros guardavam por ela e que não permitirá que lhe façam nunca algum mal

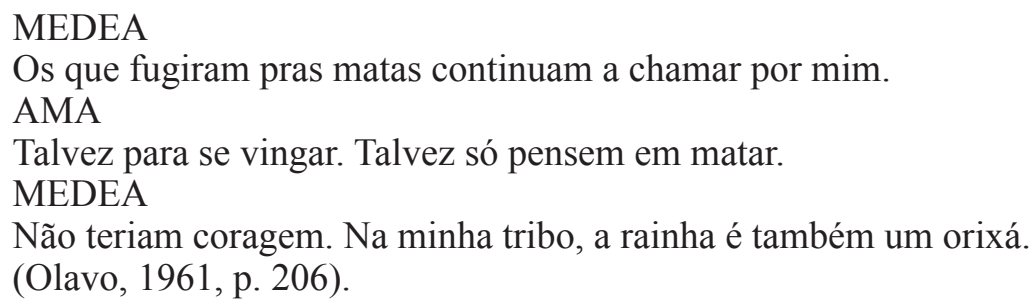

Medea se recusa a voltar ao seu povo, a se desvencilhar do domínio do branco, mas sabe do seu poder, tem consciência de sua posição, embora negue as obrigações que estão ligadas a ela.

Se Jinga, quando deixou seu povo, matou pai e irmão para fugir com o "vendedor de escravos", a dívida é paga com a vida dos filhos, devolvidos às mesmas águas que a trouxeram com Jasão. Ela mata para atravessar o mar com Jasão e paga para voltar ao seu povo, novamente matando, dessa vez os filhos brancos que gerara

\footnotetext{
6 Orum significado O Além, o Céu. Cf. Tenda de Umbanda de Ossanha. Dispo-

nível em: <http://www.tendadeumbanda.com.br/olorum_26.html>.
} 
nessa vida com Jasão. “Nos ciclos religiosos, no candomblé Oxumaré representa esse ciclo" (Semog, Nascimento, 2006, p. 34), esse ir e vir dos caminhos que nos pertencem e aos quais nós pertencemos, mas de que tentamos, de alguma forma, escapar e acabamos reencontrando-os nas encruzilhadas.

São muitas as características que o teatro negro deixa entrever em suas fissuras nessa dramaturgia que carrega uma possível intenção de colocar em primeiro plano uma cultura até então menosprezada. O próprio Abdias do Nascimento declarou e insistiu na necessidade de ocupação de um novo lugar advindo da criação de uma dramaturgia específica. Carecia, assim, entre a classe teatral, de incentivar e praticar um teatro verdadeiramente negro e, consequentemente, verdadeiramente brasileiro, já que até então se podia verificar, com mais força, uma submissão estética.

\begin{abstract}
O espetáculo brasileiro é um espetáculo europeu, espelha uma sociedade que não é a verdadeira sociedade brasileira. Quando a sociedade brasileira exclui o negro como o protagonista, como o principal, ela é uma sociedade alienada. Porque o Brasil foi construído pelo negro, o negro é a maioria nesse país, ele, em geral, está ausente no teatro brasileiro, porque o teatro corresponde a uma exigência, a um pedido público. E o público que vai ao teatro é exatamente esse público alienado, essa classe média que quer ser burguesa, quer ser europeia, que só se vê falar em francês e em coisas americanas. O Teatro Experimental do Negro veio também para enfrentar esse problema e inserir, nesse contexto de alienação da dramaturgia e do espetáculo, um outro tipo de alternativa estética, que é mostrar o negro como um valor estético autenticamente brasileiro (Semog, Nascimento, 2006, p. 123 , grifo nosso).
\end{abstract}

Esse novo valor estético tem a ver, antes de tudo, com colocar em cena o negro protagonista e as histórias do negro que dizem respeito, muitas vezes, à discriminação, mas também à conquista do seu espaço, da necessidade de falar, de reagir, de se exprimir e de levar para cena essa herança diaspórica.

Frente a um panorama teatral repleto de representações que enalteciam os estereótipos relacionados à cultura, à religiosidade e à imagem das personagens negras que objetivam a inferiorização de toda influência negra na cultura brasileira, o teatro negro, através de seus textos e suas montagens, quer inverter os paradigmas da representação então vigente dando foco positivo a esses elementos da cultura africana herdados e negados ou camuflados pelo teatro ocidental, fortalecendo sua presença na estética do teatro brasileiro e permitindo sua total realização.

Além do Rio, coloca em primeiro plano o personagem negro, com suas histórias, musicalidade e rituais e consequentemente aborda a questão do negro no teatro ao dar oportunidade para que atores negros tenham grandes personagens a interpretar. O protagonista branco sai de cena, o que representa uma mudança desses paradigmas tradicionalmente impostos.

\title{
Referências
}

ALMEIDA, Wilson Filho Ribeiro de. A personagem Medea no teatro de Agostinho Olavo: um estudo de feitiçaria africana. Revista InterteXto, Uberaba, v. 3, n. 2, p. 82-106, jul.-dez. 2010. 
BEZERRA FILHO, Feliciano José. O samba e a identidade do negro no Brasil. Anais do XI Congresso Internacional da ABRALIC, São Paulo, USP, 2008. Publicação sem numeração de página. Disponível em: <http://www.abralic.org.br/anais/cong2008/ AnaisOnline/simposios/pdf/078/FELICIANO_FILHO.pdf>. Acesso em: 14 fev. 2012.

CÂNDIDO, Maria Regina. Medéia, mito e magia: a imagem através do tempo. Rio de Janeiro: NEA/UERJ, Fábrica do Livro/ SENAI, 2006/2007. Disponível em: <http://www. nea.uerj.br/publica/e-books/medeia_mito_e_magia.pdf>. Acesso em: 14 ago. 2012.

CASTRO, Hebe M. Mattos de. Laços de família e direitos no final da escravidão. In: ALENCASTRO, Luiz Felipe de (Org.). História da vida privada no Brasil. v. 2: Império: a corte e a modernidade nacional. São Paulo: Companhia das Letras, 1997. p. 337-383.

COELHO, Maria Cecília de Miranda Nogueira. Medéia: metamorfoses do gênero. Letras Clássicas, São Paulo, FFLCH/USP, v. 1, n. 9, p. 157-178, 2005. Disponível em: <http://www.revistas.fflch.usp.br/letrasclassicas/article/view/721>. Acesso em: 30 ago. 2012.

DUARTE, Eduardo de Assis. Literatura afro-brasileira: um conceito em construção. Estudos de Literatura Brasileira contemporânea, Brasília, n. 31, p. 11-23, jan.-jun. 2008.

EURÍPIDES, c. 480-406 a.C. Medeia. Trad. Trajano Vieira. São Paulo: Ed. 34, 2010.

LIMA, Evani Tavares. Teatro negro, existência por resistência: problemáticas de teatro brasileiro. Repertório: teatro e dança, Salvador, UFBA, n. 17, p. 82-88, 2011. Disponível em: <http://www.repositorio.ufba.br/ri/handle/ri/5665>. Acesso em: 7 jul. 2012.

Um olhar sobre o Teatro Negro do Teatro Experimental do Negro e do Bando de Teatro Olodum. 279f. Tese (Doutorado em Artes). UNICAMP, Campinas, 2010. Disponível em: <http://www.bibliotecadigital.unicamp.br/document/?code $=000778472$ $\mathrm{fd}=\mathrm{y}>$. Acesso em: 3 nov. 2012.

LIMA, Mariângela Alves de. O teatro negro no Brasil e nos Estados Unidos. Revista USP, São Paulo, n. 28, p. 257-260, dez. 1995-fev. 1996

MARTINS, Leda Maria. A cena em sombras: expressões do teatro negro no Brasil e nos Estados Unidos. 275f. Tese (Doutorado em Literatura Comparada). UFMG: Belo Horizonte, 1991.

Afrografias da memória: o Reinado do Rosário no Jatobá. São Paulo: Perspectiva; Belo Horizonte: Mazza Edições, 1997.

MUNANGA, Kabengele. Negritude: usos e sentidos. 3. ed. Belo Horizonte: Autêntica, 2012. 
NASCIMENTO, Abdias do. Teatro Experimental do Negro: trajetória e reflexões. Estudos Avançados, São Paulo, v. 15, n. 50, p. 209-224, 2004.

OLAVO, Agostinho. Além do rio. In: NASCIMENTO, Abdias do. Dramas para negros e prólogo para brancos: antologia do teatro brasileiro. Rio de Janeiro: TEN, 1961.

PAULA, Benjamim Xavier de. Das teorias racistas às diásporas africanas: o negro na sociedade brasileira. Anais Eletrônicos do XI Congresso Luso-Afro-Brasileiro de Ciências Sociais: diversidades e desigualdades. Salvador/BA: Universidade Federal da Bahia; Centro de Estudos Afro-orientais - CEAO/UFBA, v. 1, p. 1-16, 2011.

SANTIAGO, Silviano. Uma literatura nos trópicos: ensaios sobre dependência cultural. São Paulo: Perspectiva, 1978.

SEMOG, Éle; NASCIMENTO, Abdias do. Abdias do Nascimento: o griot e as muralhas. Rio de Janeiro: Pallas, 2006. 